Arq. Bras. Med. Vet. Zootec., v.66, n.6, p.1771-1778, 2014

\title{
Fate of non 0157 Shigatoxigenic Escherichia coli in ovine manure composting
}

\author{
[Eliminação de Escherichia coli Shigatoxigênica não O157 em compostagem \\ de esterco ovino]

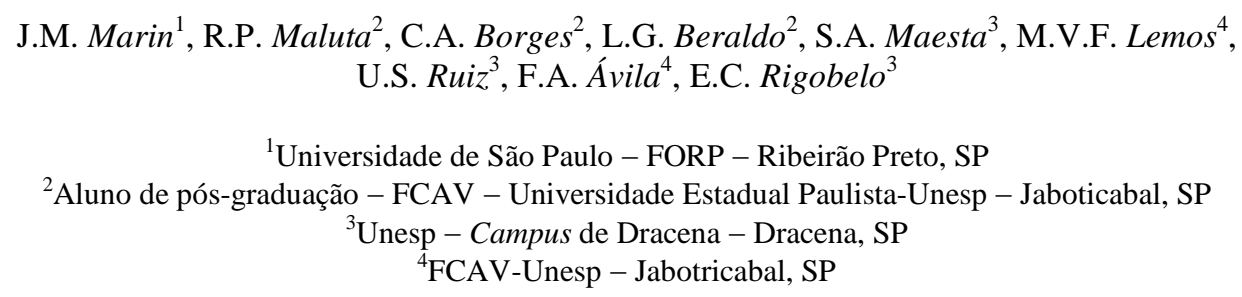

\begin{abstract}
Livestock manure may contain pathogenic microorganisms which pose a risk to the health of animal or humans if the manure is not adequately treated or disposed of. To determine the fate of Shiga toxigenic Escherichia coli (STEC) non $\mathrm{O} 157$ in composted manure from naturally colonized sheep, fresh manure was obtained from animals carrying bacterial cells with st $1 /$ st $x 2$ genes. Two composting systems were used, aerated and non-aerated, and the experiments were done in Dracena city, São Paulo State. Every week, for seven weeks, one manure sample from six different points in both systems was collected and cultured to determine the presence of $E$. coli, the presence of the virulence genes in the cells, and also the susceptibility to 10 antimicrobial drugs. The temperature was verified at each sampling. STEC non-O157 survived for 49 days in both composting systems. E. coli non-STEC showing a high degree of antibiotic resistance was recovered all long the composting period. No relationship was established between the presence of virulence genes and antibiotic resistance. The presence of virulence genes and multiple antibiotic resistances in E. coli implicates a potential risk for these genes spread in the human food chain, which is a reason for concern.
\end{abstract}

Keywords: bacterial elimination, VTEC, environment, compost, virulence gene

\section{RESUMO}

Esterco de animais de criação pode conter microrganismos patogênicos, o que representa um risco para a saúde animal e a humana se o esterco não for adequadamente tratado ou descartado. Determinou-se o tempo necessário para a eliminação de Escherichia coli Shiga toxigenica (STEC) não O157 em esterco ovino composto, obtido de fezes frescas de ovelhas naturalmente colonizadas com cepas STEC não O157 que apresentavam os genes stx1/ stx2. Foram utilizados dois sistemas de compostagem, aerado e não aerado, em experimentos realizados na cidade de Dracena, estado de São Paulo. Todas as semanas, durante sete semanas, uma amostra de compostagem proveniente de seis pontos diferentes na leira, nos dois sistemas, foi coletada e semeada para a determinação da presença de E. coli, da presença de genes de virulência nas células, bem como da sensibilidade dessas células a 10 drogas antimicrobianas. Em cada amostragem, a temperatura da leira foi analisada. Células de STEC não O157 sobreviveram por 49 dias nos dois sistemas de compostagem. E. coli não STEC com um alto grau de resistência a antibióticos foi recuperada ao longo de todo o período de compostagem. Não foi possível estabelecer relação entre a presença de genes de virulência e a resistência a antibióticos. A presença de genes de virulência e a resistência a múltiplos antibióticos em E. coli representam um risco potencial para o espalhamento desses genes na cadeia alimentar humana, o que é motivo de grande preocupação.

Palavras-chave: eliminação de bactéria, VTEC, meio ambiente, esterco, genes de virulência 


\section{INTRODUCTION}

Composting is a traditional way to treat livestock manure to make it easier to dispose of on land, and to produce an inexpensive fertilizer. However, livestock manure may contain zoonotic microbial pathogens, including Salmonella spp and Shiga toxigenic Escherichia coli (STEC) producing a Shiga-like toxin (stx1 and/or stx2) (Nicholson et al., 2005).

Since the emergence of STEC as human pathogens, contamination of foods of animal origin has been a major public health concern. Ruminants, among them cattle and sheep, sporadically harbor STEC strains in their gastrointestinal tracts and shed the bacteria in their feces (Kudva et al., 1998). E. coli O157:H7 is one of the leading causes of bacterial diarrhea and hemorrhagic colitis, showing two antigenically different forms of Shiga toxin, the st $x 1$ and stx2. The key virulence factor for STEC is Stx that cleaves ribosomal RNA, causing protein synthesis to cease. The Stx family contains two subgroups Stx1 and Stx2 that share approximately 55\% amino acid homology. In the kidney the Stx damages the renal endothelium cells and occludes the microvasculature resulting in renal inflammation. Stx also induces apoptosis in intestinal epithelial cells and local damage to the colon which results in blood diarrhea, hemorrhagic colitis, necrosis and intestinal perforation (Kaper et al., 2004). It has emerged as a foodborne pathogen and has been implicated in over 20,000 cases of infection and 250 deaths per year in the United States (Koutkia et al., 1997). Outbreaks have been traced to ground beef, raw milk, water, fruits and vegetables that have been contaminated with this pathogen (Lung et al., 2001). While serotype O157:H7 is the best-recognized strain, other serotypes are responsible for approximately half of all confirmed STEC infections in Europe (Bolton et al., 2011), and there is a growing concern about the risk of non-O157:H7 STEC serotypes to human health (Fremaux et al., 2007; Bolton et al., 2011).

Transfer of STEC strains to humans through contact with contaminated environments is becoming increasingly recognized as a major route of human infection, particularly infection among children (Strachan et al., 2006). A number of previous studies have shown that $E$. coli can survive for up to several months in experimentally inoculated animal feces (Kudva et al., 1998; Lung et al., 2001; Asano et al., 2011). The disinfection of manure during composting is based on the time-temperature relationship that kills the pathogens plus the action of antagonistic microorganisms during this process (Himathongkham and Rieman, 1999; Turner, 2002; Larney et al., 2003).

The E. coli strains encountered in manure can present a high degree of antimicrobial resistance. This resistance to antimicrobials is the result of the dissemination of genetic elements such as plasmids, transposons and integrons. However, there are few data regarding antimicrobial resistance to the virulence genes of STEC (Zhang et al., 2000; Mora et al., 2005) and previous studies on this issue are controversial (Clermont et al., 2008). The use of antibiotics during animal production has been a controversial subject due its potential to transfer antimicrobial resistance genes to both animals and humans. Nagachinta et al. (2009) suggested a possible relationship between conjugative plasmid in the dissemination of antimicrobial resistance genes together with pathogenicity genes.

There is limited information as to whether the presence of antimicrobial resistance genes in $E$. coli strains increases their survival times during the composting process. In the present study, the aims were to determine the fate of STEC non0157 cells in ovine manure in two different composting systems as well as to verify if there is a relationship between antimicrobial resistance patterns and virulence factors.

\section{MATERIAL AND METHODS}

During March 2010 anal swabs were collected from the rectum of ovines in a herd of 65 healthy adult sheep from a facility owned by the Graduate School of Agriculture located in Dracena city in the Northwestern region of São Paulo State, Brazil. The swabs were transferred to a bottle containing Stuart Transport Medium (BBL/Becton Dickinson, Sparks, MD, USA) and were aerobically cultured in MacConkey agar (Oxoid, Basingstoke, UK), as soon as possible. $E$. coli isolates were identified based on the colony characteristics, Gram staining and biochemical profile (Farmer, 1999). At least five 
colonies per plate were selected for further analysis. The isolates were serotyped for serotype O157:H7 using the Latex Agglutination test Kit (Oxoid, Basingstoke, UK). Negative strains were considered non-O157. E. coli EDL 933 strain was used as a positive control for O157:H7 serotype.

A loopfull of cells from each five colonies above selected was collected, mixed and grown overnight in Luria Bertani broth (Difco, Oxford, $\mathrm{UK}$ ), at $37^{\circ} \mathrm{C}$. Bacteria were pelleted from $1.5 \mathrm{~mL}$ of broth, suspended in 200uL sterile distilled water and boiled for $10 \mathrm{~min}$. Following centrifugation of the lysate, a $150 \mathrm{uL}$ sample of the supernatant was stored at $-20^{\circ} \mathrm{C}$ as a template DNA stock (Keskimaki et al., 2001). Specific primers were used to amplify sequences of st $x 1$, st $x 2$ and eae genes. Primer sequences, predicted sizes of the amplified products, and the specific conditions were carried out according to those described by Vidal et al. (2005). Strains carrying st $x 1$ and/or st $x 2$ genes detected by PCR method were classified as a STEC strain and those without these genes were classified as a nonSTEC strain.

The composting was performed at a field-scale facility owned by the School using fresh manure obtained from all sheep including those that have been confirmed to have non-O157 STEC strains possessing both, st $x 1$ and st $x 2$ genes. Five hundred kilograms of sheep feces were heaped for two treatments. The first one (A - aerated compost) was turned every three days during the 7 week treatment period (March to April 2010) while the second (B - non-aerated compost) was not turned and remained without revolving throughout the experiment. Three parts of dry grass and one part of sheep feces were added to each treatment to equilibrate the nutritional balance among nitrogen and carbon, which facilitates the decomposition of all material. The two heaps were $2 \mathrm{~m}$ long by $2 \mathrm{~m}$ wide by $0.5 \mathrm{~m}$ deep. Water was added daily to maintain the saturation point at $60 \%$. Under the heaps, six equidistant points were traced, and samples were obtained weekly, on Monday. At each sampling time, the temperature of the compost was determined at each specified location before any internal samples were removed from the heaps. Once these data were collected, the compost heaps were opened with a shovel and the samples were collected aseptically.
Twenty-five grams of compost samples were mixed with $225 \mathrm{~mL}$ of Tryptone Soya Broth (Oxoid, Basingstoke, UK). Decimal dilution of each homogenate were prepared in maximum recovery diluents (MRD, Oxoid, Basingstoke, UK). E. coli were enumerated by spread-plating a volume of $100 \mu \mathrm{L}$ onto MacConkey agar (Oxoid, Basingstoke, UK) plates which were incubated at $37^{\circ} \mathrm{C}$ for 18 hours. Colonies were counted and titres obtained in a colony forming unit $(\mathrm{CFU} / \mathrm{mL})$. Ten colonies per plate were selected for $E$ coli confirmation as described above. After that a loopfull of each colony was inoculated and grown overnight into Luria Bertani broth (Difco, Oxoid, UK). The template DNA stock was obtained as described above. The presence of bacteria containing the virulence genes was assayed by PCR as mentioned.

The ten isolates mentioned above were examined for susceptibility to 10 antimicrobial drugs using the Bauer-Kirby disc diffusion method using commercial disks (CEFAR, São Paulo, Brazil). The following discs were used: ampicillin (Amp, $10 \mu \mathrm{g}$ ), tetracycline (Tet, $30 \mu \mathrm{g}$ ), trimethoprim (Tri, $25 \mu \mathrm{g})$, erythromycin (Eri, $15 \mu \mathrm{g}$ ), nalidixic

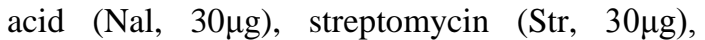

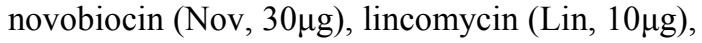

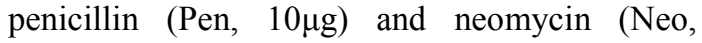

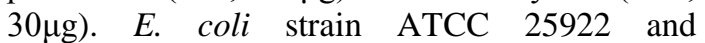
Staphilococus aureus strain ATCC 29213 were used for quality control. Isolates were classed as sensitive, intermediate and resistant to each drug according to Committee for Laboratory Standards Institute (CLSI, 2008).

\section{RESULTS}

The average changes in E. coli number in the composting system are shown in Table 1 . Samples were taken from six equidistant points inside the heap for both $\mathrm{A}$ and $\mathrm{B}$ composting treatments. Eighty-four compost samples were collected for further analysis from both composting $(\mathrm{A}=42 ; \mathrm{B}=42)$, the temperature fluctuations were also analyzed during this time. For treatment A the suitable temperature for the reduction or elimination of the pathogenic microorganisms was reached in the first week around $55^{\circ} \mathrm{C}$, while for $\mathrm{B}$ this marker was found only in the second week. A total of $695 \mathrm{E}$. coli isolates (321 from treatment $\mathrm{A}$ and 374 from treatment B) were obtained from the MacConkey plates during the seven weeks of experiment. 


\section{Marin et al.}

Although the total number of $E$. coli isolates carrying virulence genes decreased weekly throughout the experiment, the values found for treatment $\mathrm{B}$ (non-aerated) were higher than for treatment A (Figure 1A, B). Tab.2 shows all the isolates encoding virulence genes recovered in both treatments. The values for treatment $\mathrm{B}$ were 55, 65 and 30 and for treatment A 22, 49 and 6 respectively, for st $x 1$, st 2 and eae genes (Table 2). A decrease in the volume of material was larger for treatment A when compared with treatment B (data not shown) which was probably the result of a better decomposition.
The serotype O157:H7 was not found among the isolates recovered from both treatments. The STEC strains carrying the $s t x 2$ gene (the most numerous virulence gene) and also non-STEC strains showed a high degree of antimicrobial resistance for the 10 drugs tested, as shown in Figure 2; there was a high similarity among the antimicrobial resistance patterns for both strains. Bacterial isolates with multiple antimicrobial resistance were recovered in both treatments, for both kinds of strains, and during the entire period of the experiment (data not shown).

Table 1. Evaluation of the E. coli number and temperature during composting in aerated (Treatment A) and non-aerated (Treatment B) systems. Each data is the mean of the six equidistant points inside the heaps

\begin{tabular}{ccccc}
\hline & \multicolumn{2}{c}{ Composting A (aerated) } & \multicolumn{2}{c}{ Composting B (non-aerated) } \\
\hline Week & CFU/mL & Temperature $\left({ }^{\circ} \mathrm{C}\right)$ & CFU/mL & Temperature $\left({ }^{\circ} \mathrm{C}\right)$ \\
\hline 1 & 934 & 58 & 1234 & 47 \\
2 & 540 & 61 & 935 & 51 \\
3 & 510 & 66 & 624 & 61 \\
4 & 278 & 34 & 178 & 35 \\
5 & 34 & 19 & 23 & 22 \\
6 & 21 & 22 & 15 & 21 \\
7 & 14 & 14 & 14 & 14 \\
\hline
\end{tabular}
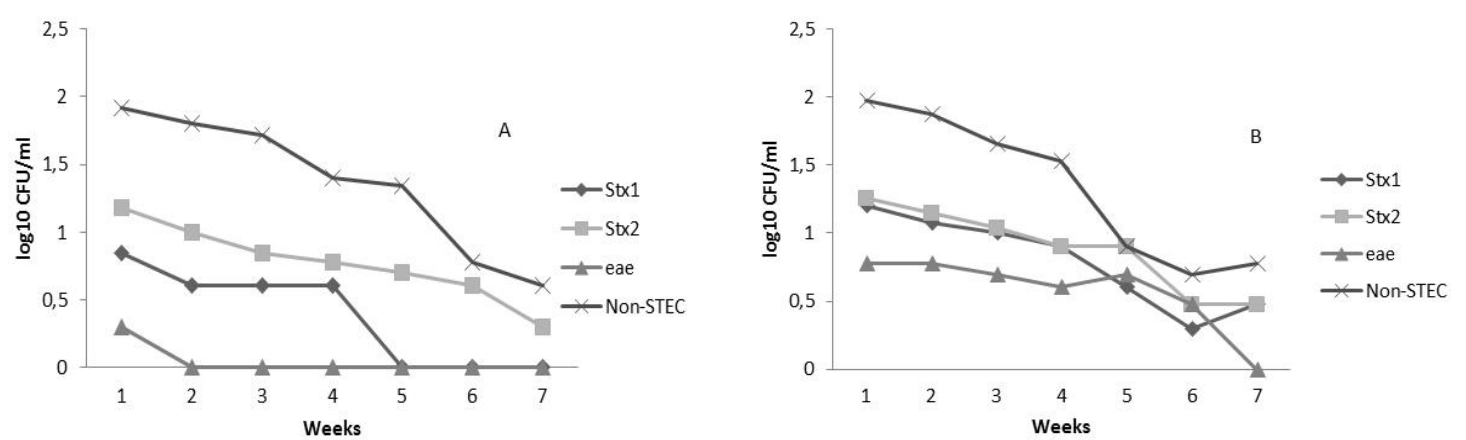

Figure1 A, B. Fate of E. coli strains during composting. A: aerated treatment, B: non- aerated treatment.

Table 2. Virulence genes of E. coli isolates obtained from an ovine manure-based composting (n= 695 isolates)

\begin{tabular}{lcc} 
& \multicolumn{3}{c}{ Number of isolates } \\
\hline genotype & Composting A (aerated) & Composting B (non-aerated) \\
\hline stx 1 & 16 & 26 \\
stx 1 / eae & 1 & 16 \\
stx 2 & 40 & 45 \\
stx 2/ eae & 4 & 7 \\
stx 1/ stx 2 & 4 & 6 \\
stx 1/ stx 2/ eae & 1 & 7 \\
non-STEC & 255 & 267 \\
Total & 321 & 374 \\
\hline
\end{tabular}




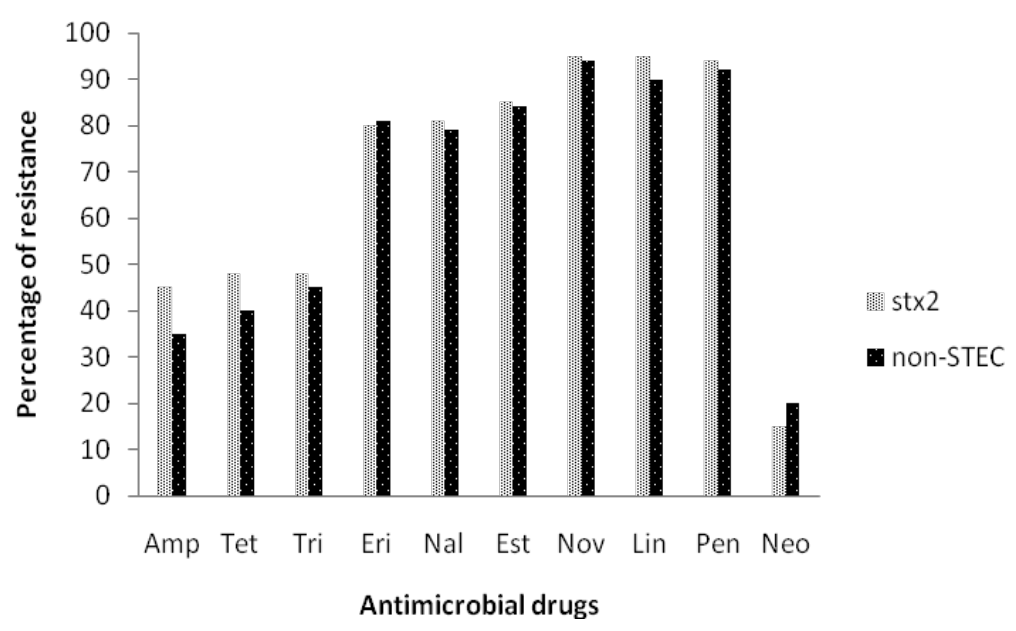

Amp-ampicillin; Tet-tetracycline; Tri-trimethoprim; Eri-erythromycin; Nal-nalidixic acid; Est-streptomycin; Novnovobiocin; Lin-lincomycin; Pen-penicillin; Neo-neomycin

Figure 2. Antimicrobial resistance patterns of 114 E. coli isolates all carrying stx 2 gene and 234 E. coli non-STEC strains, both from composting systems.

\section{DISCUSSION}

There is a growing public concern about the link between livestock production and soil contamination by pathogenic bacteria. This is especially true for the application of raw manure, which is potentially capable of spreading pathogens to a wider environment (Turner, 2002; Nicholson et al., 2005; Bolton et al., 2011). Some foodborne disease outbreaks have been associated with manure contamination of fresh produce with STEC strains, especially O157:H7 (Islam et al., 2005) but also with non-O157 strains (Bolton et al., 2011). Sheep harbor many serotypes of STEC in their gastrointestinal tract; many of them associated with disease in humans and spread them to the environment by fecal shedding (Kudva et al., 1998; Vettorato et al., 2003).

Although the elimination of pathogens by composting has been well documented (Larney et al., 2003; Nicholson et al., 2005), composting time and temperatures required to achieve elimination or reduction of the number of $E$. coli vary widely. Turner (2002) demonstrated inactivation of $E$. coli in farmyard manure after 2 hours at $55^{\circ} \mathrm{C}$. Lung et al. (2001) described an effectively reduction in the $E$. coli $\mathrm{O} 157: \mathrm{H7}$ number after 4 days at $45^{\circ} \mathrm{C}$. In contrast, Nicholson et al. (2005) reported the recuperation of E. coli $\mathrm{O} 157$ from manure heaps after 32 days of composting. In the present study the suitable temperature for the reduction or elimination of the pathogenic microorganisms for both composting treatments was reached around the first and the second week respectively for aerated and non-aerated treatments, which agrees partially with the data reported by Nicholson et al. (2005) E. coli commensal isolates could be recovered from the composting systems until the seventh week, while the non-O157 STEC strains carrying st 1 or st 2 were isolated for 49 days in both composting treatments.

There have been few studies on the persistence of $E$. coli non-O157:H7 in animal feces. Gonçalves and Marin (2007) described STEC non-O157 survival for 25 and 30 days at $40^{\circ} \mathrm{C}$ and $38^{\circ} \mathrm{C}$ respectively in a bovine manure-based composting. Fremaux et al. (2007) reported the elimination of non-O157 cells submitted to composting in manure heaps after nine and 16 days at $65^{\circ} \mathrm{C}$ and $56^{\circ} \mathrm{C}$ respectively, indicating that temperature is a key factor in the elimination and/or reduction of the viable cells. Not only temperature but also the interactions among the different types of bacteria and fungi inside of the composting system is important (Himathongkham and Rieman, 1999; Turner, 2002; Larney et al., 2003) which could explain some differences between bovine and ovine 
manure, it should be better analyzed in the future.

Vettorato et al. (2003) reported the isolation of 42 STEC strains (not one was O157:H7) in 48 sheep from two farms in São Paulo State, Brazil. Twenty-one of these strains (50.0\%) were positive for stx1/ stx2 genes while $38.1 \%$ and $11.9 \%$ were positive for stx 1 or stx 2 only, respectively. In the present study the stx 2 gene was the most commonly detected virulence factor and only a small number of cells carrying st $x 1 /$ st $x 2$ was detected, which does not agree with the data reported by Vettorato et al. (2003), another different aspect of this study is the recuperation of the eae gene among the isolates together with st $x 1$ and /or stx2. The serotypes carrying this gene have been linked with severe illness such as hemorrhagic colitis (Oswald et al., 2000).

There is evidence that antimicrobial-resistant bacteria originating from livestock can be transferred to humans (van den Bogaard and Stobberingh, 2000) thus emphasizing the importance of mitigating their spread into the environment. Most studies on the persistence of antimicrobial-resistant bacteria in livestock waste have focused on large scale management systems including stored manure (Duriez and Topp, 2007) or manure applied to soil (Schmitt et al., 2006) and have used viable bacteria to describe resistance levels. Alexander et al. (2011) investigated the persistence of antimicrobial resistance genes sampled in $E$. coli strains from cattle feces under ambient field conditions and they reported persistence for 175 days. In this study a high degree of resistance to 10 antimicrobial drugs was found among STEC non-O157 strains and also in non-STEC strains, in agreement with the data reported by Mora et al. (2005), who verified that there was no difference in the antimicrobial resistance patterns of STEC strains when compared to non-STEC strains.

Dopfer et al. (2010) reported the analyses of 150 E. coli isolates from 2 sheep, sampled over 3 weeks, which were characterized by serotyping, virulotyping and genotyping. Sheep carried $E$. coli that encode for virulence markers and belong to serogroups known to be human pathogens. Most of the isolates were found to be susceptible to horizontal transfer of Shiga toxin genes by means of bacteriophages in vitro. Duriez et al. (2008) report that during commercial manure storage, there was a significant reduction in the carriage of virulence genes by E. coli. Forty-eight fecal isolates of $E$. coli that varied in their genotypes and virulence gene complement were inoculated in diffusion chambers in the manure holding tank for 3 weeks. Over $95.0 \%$ of the inoculums populations carried at least one virulence gene, whereas after 3 weeks $90.0 \%$ of the recovered isolates carried no virulence genes. In the present study no relationship could be set up involving the presence of virulence genes and antimicrobial resistance, as shown in Fig.2, STEC strains carrying the stx2 gene and non-STEC strains exhibited the same patterns of antimicrobial resistance, both cells showing multiple antibiotics resistance were isolated all the time during the experiment (data not shown). So it was not possible to verify any alteration in the recovering of bacterial cells carrying virulence genes or antimicrobial resistance.

It is well known that STEC is widespread in animal feces, therefore, the application of untreated ovine manure to vegetable cultures may pose a risk for the transmission of STEC to food. Composting is a practical method that can effectively eliminate pathogens in manure, or at least promote a reduction in the number of pathogenic cells. Thus, even small reductions in the prevalence of zoonotic agents would significantly lower the risk of pathogen dissemination. In conclusion, it was shown that STEC non-O157 strains carrying virulence genes (stx1, stx2) can survive in an ovine-based composting for 49 days in both aerated or nonaerated systems. Unfortunately it was shown that both E. coli cells, STEC or non-STEC, during the period of composting did not lose their virulence genes and/or the antibiotic resistance genes.

\section{ACKNOWLEDGMENTS}

The authors acknowledge FAPESP for the funding supply $n^{0}$ 2008/00434-2. 


\section{REFERENCES}

ALEXANDER, T.W.; YANKE, J.L.; REUTER, $\mathrm{T}$. et al. Longitudinal characterization of antimicrobial resistance genes in feces shed from cattle fed different subtherapeutic antibiotics. BMC Microbiol., v.11, p.1-12, 2011.

ASANO, R.; KUBORI, K.; OZUTSUMI, Y. et al. Detection of Escherichia coli in a cattle manure composting process by selective cultivation and colony polymerase chain reaction. J. Environ. Sci. and Health Part B, v.46, p.122-127, 2011.

BOLTON, D.J.; MONAGHAN, A.; BYRNE, B. et al. Incidence and survival of non-O157 verocytotoxigenic Escherichia coli in soil. $J$. Appl. Microbiol., v.111, p.484-490, 2011.

CLERMONT, O.; LAVOLLAY, M.; VIMONT, S. et al. The CTX-M-15-producing Escherichia coli diffusing clone belongs to a highly virulent B2 phylogenetic subgroup. J. Antimicrob. Chemother., v.61, p.1024-1028, 2008.

CLSI. Clinical and Laboratory Standards Institute. Performance standards for antimicrobial disks and dilution susceptibility tests for bacteria isolated from animals. Approved Standard 3rd edition, Wayne, PA, 2008, 182p.

DOPFER, D.; SEKSE, C.; BEUTIN, L. et al. Pathogenic potential and horizontal gene transfer in ovine gastrointestinal Escherichia coli. J. Appl. Microbiol., v.108, p.1552-1562, 2010.

DURIEZ, P.; TOPP, E. Temporal dynamics and impact of manure storage on antibiotic resistance patterns and population structure of Escherichia coli isolates from a swine farm. Appl. Environ. Microbiol., v.73, p.5486-5493, 2007.

DURIEZ, P.; ZHANG, Y.; LU, Z. et al. Loss of virulence in Escherichia coli populations during manure storage on a commercial swine farm. Appl. Environ. Microbiol., v.74, p.3935-3942, 2008.

FARMER, J.J. Enterobacteriaceae: Introduction and identification. In: MURRAY, P.R.; BARON, E.J.; PHALER, F.C. et al. (eds). Manual of Clinical Microbiology. 7.ed. Washington: ASM, 1999, 1795p.
FREMAUX, B.; DELIGNETTE-MULLER, M.L.; PRIGENT-COMBARET, C. et al. Growth and survival of non-O157: H7 Shiga toxinproducing Escherichia coli in cow manure. $J$. Appl. Microbiol., v.102, p.89-99, 2007.

GONÇALVES, V.P.; MARIN, J.M. Fate of non O157 Shiga toxigenic Escherichia coli in composted cattle manure. Arq. Bras. Med. Vet. Zootec., v.59, p.825-831, 2007.

HIMATHONGKHAM, S.; RIEMANN, H. Destruction of Salmonella typhimurium, Escherichia coli O157:H7 and Listeria monocytogenes in chicken manure by drying and/or gassing with ammonia. FEMS Microbiol. Lett., v.171, p.179-182, 1999.

ISLAM, M.; DOYLE, M.P.; PHATAK, P. et al. Survival of E. coli O157: H7 on carrots and onions grown in fields treated with contaminated manure composts or irrigation water. Food Microbiol., v.22, p.63-70, 2005.

KAPER, J.B.; NATARO, J.P.; MOBLEY, H.L.T. Pathogenic Escherichia coli. Nature Rev. Microbiol., v.2, p.123-140, 2004.

KESKIMAKI, M.; ATTILA, L.; PELTOLA, et al. EPEC, EAC and STEC in stool specimens: Prevalence and molecular epidemiology of isolates. Diag. Microbiol. Infect. Dis., v.40, p.151-156, 2001.

KOUTKIA, P.; MYLONAKIS, E.; FLANIGAN, T. Enterohemorrhagic E. coli O157:H7 - an emerging pathogen. Am. Family Physician, v.56, p.853-856, 1997.

KUDVA, I.T.; BLANCH, K.; HOYDE, C.J. Analysis of Escherichia coli O 157: H7 survival in ovine or bovine manure and manure slurry. Appl. Environ. Microbiol., v.64, p.3166-3174, 1998.

LARNEY, F.J.; YANKE, L.J.; MILER, J.J. et al. Fate of coliform bacteria in composted beef cattle feedlot manure. J. Environ. Qual., v.32, p.1508-1515, 2003.

LUNG, A.J.; LIN, C.M.; KIM, J.M. et al. Destruction of Escherichia coli O157:H7 and Salmonella enteritidis in cow manure composting. J. Food. Prot., v.64, p.1309-1314, 2001. 
MORA, A.; BLANCO, J.E.; BLANCO, M. et al. Antimicrobial resistance of Shiga toxin (verotoxin)-producing Escherichia coli O157: H7 and non-O157 strains isolated from humans, cattle, sheep and food in Spain. Res. Microbiol., v.156, p.793-806, 2005.

NAGACHINTA, S.; CHEN, J.; LI, R. et al. Integron-mediated antibiotic resistance in Shiga toxin-producing Escherichia coli. J. Food. Prot., v.72, p.21-27, 2009.

NICHOLSON, F.A.; GROVES, S.J.; CHAMBERS, B.J. Pathogen survival during livestock manure storage and following land application. Bioresour. Technol., v.96, p.135143, 2005.

OSWALD, E.; SCHMIDT, H.; MORABITO, S. et al. Typing of intimin genes in human and animal enterohemorrhagic and enteropathogenic Escherichia coli: characterization of a new intimin variant. Infect. Immun., v.68, p.64-71, 2000 .

SCHMITT, H.; STOOB, K.; HARRISCHER, G. et al. Tetracyclines and tetracycline resistance in agricultural soils: microcosm and field studies. Microbiol. Ecol., v.51, p.267-276, 2006.

STRACHAN, N.J.; DUNN, G.M.; LOCKING, M.E. et al. Escherichia coli O157: burger bug or environmental pathogen? Int. J. Food. Microbiol., v.112, p.129-137, 2006.
TURNER, C. The thermal inactivation of Escherichia coli in cow and pig manure. Bioressour. Technol., v.84, p.57-61, 2002.

Van den BOGAARD, A.F.; STOBBERINGH, E.E. Epidemiology of resistance to antibiotics links between animals and humans. Int. J. Antimicrob. Agents, v.14, p.327-335, 2000.

VETTORATO, M.P.; LEOMIL, L.; GUTH, B.E.C. et al. Properties of Shiga toxin-producing Escherichia coli (STEC) isolates from sheep in the State of São Paulo, Brazil. Vet. Microbiol., v.95, p.103-109, 2003.

VIDAL, M.; KRUGER, E.; DURAN, C. et al. Single multiplex PCR assay to identify simultaneously the six categories of diarrheagenic Escherichia coli associated with enteric infections. J. Clin. Microbiol., v.43, p.5362-5365, 2005.

ZHANG, X.A.D.; MCDANIEL, L.E.; WOLF, G.T. et al. Quinolone antibiotics induce Shiga toxin-encoding bacteriophages, toxin production, and death in mice. J. Infect. Dis., v.181, p.664670, 2000. 